\title{
Peran Dukungan Sosial Teman Sebaya terhadap Regulasi Emosi Mahasiswa Perantau Tahun Pertama di Jakarta
}

\section{The Role Of Peer Social Support Toward Emotion Regulation of Migrated Student in the First Year in Jakarta}

\author{
Weldina Siswandi, Riselligia Caninsti \\ Fakultas Psikologi Universitas YARSI, Jakarta, Indonesia \\ Email: riselligia.caninsti@yarsi.ac.id
}

KATA KUNCI

KEYWORDS

ABSTRAK
Regulasi Emosi, Dukungan Sosial Teman Sebaya, Mahasiswa Perantau

\section{Emotion Regulation, Peer Social Support, Migrated Student}

Individu yang tidak dapat beradaptasi dan kesulitan dalam menghadapi permasalahan emosional dapat membawanya ke dalam masalah yang lebih kompleks. Kemampuan meregulasi emosi dapat membuat mahasiswa perantau memiliki keyakinan pada diri sendiri dan menyadari kekuatan serta keterbatasan diri. Dukungan sosial merupakan salah satu faktor yang dapat mendukung individu melakukan regulasi emosi. Pada mahasiswa perantau tahun pertama, adanya keberadaan teman sebaya merupakan sosok yang penting. Teman sebaya diharapkan memberikan dukungan kepada mahasiswa perantau tahun pertama yang tinggal berjauhan dari orangtua .Tujuan penelitian ini adalah untuk mengetahui seberapa besar peran dukungan sosial teman sebaya terhadap regulasi emosi mahasiswa yang merantau di Jakarta pada tahun pertama. Penelitian ini menggunakan pendekatan kuantitatif dengan menggunakan skala Emotion Regulation Questionnaire $(\alpha=0,745)$ dan skala dukungan sosial teman sebaya $(\alpha=0,972)$. Penelitian ini menggunakan teknik accidental sampling dengan jumlah partisipan sebanyak 120 responden. Analisis data penelitian menggunakan metode statistik regresi sederhana. Hasil penelitian menunjukkan bahwa dukungan sosial teman sebaya berperan signifikan terhadap strategi cognitive reappraisal $\left(\mathrm{p}=.003 \mathrm{R}^{2}=.072\right)$ Sementara itu peran dukungan sosial teman sebaya terhadap strategi regulasi emosi expressive suppression $\left(\mathrm{p}=.114 \mathrm{R}^{2}=.021\right)$. Artinya, apabila individu mendapatkan dukungan dari teman sebaya maka ia akan lebih mempertimbangkan emosi yang dirasakan untuk diekspresikan kepada lingkungan sekitar.

Individu who cannot adapt and have difficulty in dealing with emotional problems can lead to more complex problems. The ability to regulate emotions can make students have confidence in themselves, or have the ability to depend on themselves and realize their strengths and limitations. Social support is one of the factors that can support individuals to regulate emotions. First year migrated students are in the 
stage of adolescent development so that the existence of peers is an important figure. The purpose of this research is to find how big the role of the peer social support toward emotion regulation of first year migrated student college in Jakarta is. This research use a quantitative approach with Emotion Regulation Questionnaire scale $(\alpha=0.745)$ and Peer social support scale $(\alpha=0.972)$. This research use accidental sampling technique with total 120 respondents. The subject in this study were first year migrated student, Consist of an age range 17-21 years old, and regular student in Jakarta University. Using statistical method in the form of simple regression, it was found that peer social support has a significant role in cognitive reappraisal strategy $(p=.003$ $R^{2}=.072$ ). While the role of peer social support toward expressive suppression strategy is $\left(p=.114 R^{2}=.021\right)$. From the result of the research if someone gets support from their peer groups they will consider their emotion to express it to the environment.

\section{PENDAHULUAN}

Data Statistik Kementerian Riset, Teknologi dan Pendidikan Tinggi di Indonesia tahun 2018 menunjukkan jumlah mahasiswa baru yang terdaftar di Jakarta sebanyak 286.205 orang. Jumlah tersebut paling banyak jika dibandingkan dengan provinsi lain, seperti Jawa Timur, sebanyak 228.702 mahasiswa dan Jawa Barat dengan 209.555 mahasiswa (Kemenristekdikti, 2018). Jakarta menjadi salah satu kota yang diminati oleh mahasiswa dari berbagai daerah untuk melanjutkan pendidikan ke Perguruan Tinggi. Survei yang dilakukan oleh peneliti terhadap mahasiswa di Fakultas Psikologi Universitas YARSI angkatan 2016, menemukan bahwa dari 47 orang mahasiswa, terdapat 13 orang mahasiswa bukan merupakan warga Jakarta. Tiga belas orang mahasiswa tersebut berasal dari berbagai daerah di luar Jakarta, seperti Bandung, Kalimantan, Riau, Padang dan lain-lain.

Beberapa faktor menarik yang membuat individu bermigrasi ke daerah lain, diantaranya adalah sistem politik yang lebih menjamin kebebasan bagi individu, keamanan yang lebih baik dan perekonomian yang lebih berkembang. Bekerja di Jakarta seperti menawarkan penghasilan yang lebih tinggi dari daerah asal (Nastalia, 2007). Berdasarkan wawancara peneliti kepada tiga orang mahasiswa perantau di Jakarta, sebagian besar dari mereka meninggalkan kampung halaman dan berkuliah di Jakarta karena Universitas di Jakarta memiliki fasilitas yang lengkap, berteknologi tinggi dan memiliki kesempatan untuk magang di perusahaan-perusahaan besar dan bergengsi.

Mahasiswa perantau adalah individu yang tinggal di daerah lain untuk menuntut ilmu di Perguruan Tinggi dan mempersiapkan diri dalam pencapaian suatu keahlian di jenjang Perguruan Tinggi tingkat Diploma, Sarjana, Magister atau Spesialis (Lingga \& Tuapattinaja, 2012). Mahasiswa perantau juga dapat diartikan sebagai mahasiswa yang memilih untuk meninggalkan kampung halaman demi melanjutkan pendidikan yang lebih baik (Saniskoro \& Akmal, 2017). Gunarsa dan Gunarsa (2004) mengatakan mahasiswa memiliki tantangan tersendiri ketika memasuki dunia perkuliahan, mulai dari perubahan sifat pendidikan, perbedaan dalam hubungan sosial, pemilihan bidang studi atau jurusan, dan masalah ekonomi. Masalah unik yang dialami mahasiswa perantau adalah masalah psikososial, seperti tidak familiar dengan gaya dan norma sosial yang baru, perubahan pada sistem dukungan, serta masalah intrapersonal dan interpersonal yang disebabkan oleh penyesuaian diri (Saniskoro \& Akmal, 2017). Masalah lain yang dialami mahasiswa perantau adalah terkait 
akademik, seperti perencanaan studi, cara belajar dan pengenalan peraturan terhadap sistem akademik (Adiwaty \& Fitriyah, 2015), persaingan diantara mahasiswa yang lebih besar, tugas yang diberikan oleh dosen, gaya belajar yang berbeda dengan SMA, serta kualitas standar pendidikan yang lebih tinggi (Pascarella dalam Saniskoro \& Akmal, 2017).

Stressor pada mahasiswa dapat diklasifikasikan ke dalam tiga domain, yaitu berhubungan dengan bidang akademik, psikososial, dan kesehatan (Gomanthi, Ahmed, \& Sreedharan, 2013). Menurut penelitian Buckinghamshire Health Authority, terdapat berbagai macam kelompok stressor bagi mahasiswa, yaitu academic stressor, placement stressor, organizational stressor, dan personal stressor. Academic stressor diantaranya adalah jumlah tugas kuliah, organizational stressor adalah ketidakyakinan akan masa depan, placement stressor adalah perubahan tempat belajar dan personal stressor adalah kurangnya dukungan sosial (Behere, Yadav, \& Behere, 2011).

Individu yang tidak dapat beradaptasi dan kesulitan dalam menghadapi permasalahan emosional dapat membawanya ke dalam masalah yang lebih kompleks. Santrock (2003) menyatakan bahwa beberapa remaja yang tidak dapat mengelola emosinya secara efektif akan rentan mengalami depresi, kemarahan, kurang mampu meregulasi emosi, yang selanjutnya dapat memicu berbagai masalah seperti kesulitan akademis, penyalahgunaan obat, kenakalan remaja atau gangguan makan.

Salah satu contoh permasalahan emosi mahasiswa perantau ialah homesickness. Homesickness merupakan reaksi emosi yang dirasakan oleh individu karena terpisahnya individu tersebut dari rumah, orangtua, atau objek lekat tertentu. Kondisi ini membuat individu menarik diri, membutuhkan waktu untuk dapat beradaptasi dengan lingkungan yang baru ditempatinya, kurang minat pada topik yang tidak berkaitan dengan rumah, bahkan dapat membuat individu mengalami kecemasan dan depresi (Thurber \& Walton, 2012). Pada mahasiswa perantau tahun pertama, homesickness disebabkan mahasiswa baru saja berpisah tempat tinggal dengan orangtua. Umumnya, mahasiswa masih merindukan kebersamaan dengan keluarga, sehingga keinginan untuk berkumpul dan kembali ke kampung halaman semakin kuat. Halim dan Dariyo (2016) juga menemukan bahwa sebagian besar mahasiswa yang merantau merasakan kesepian. Kesepian yang dirasakan oleh mahasiswa perantau ini dapat menimbulkan dampak negatif, diantaranya: mahasiswa akan mudah merasa bosan, mengalami kesulitan untuk membangun komunikasi dengan orang lain, cenderung menutup diri, dan sulit untuk mengatasi permasalahan yang dihadapi (Cosan, 2014). Permasalahan-permasalahan yang dihadapi oleh mahasiswa perantau di atas harus diatasi agar mereka mampu beradaptasi dan bertahan di lingkungan baru.

Beberapa cara dapat dilakukan mahasiswa perantau agar mampu beradaptasi di lingkungan yang baru, salah satunya adalah dengan regulasi emosi. Menurut Tugade dan Fredickson (dalam Poegoeh \& Hamida, 2016), regulasi emosi adalah faktor yang diperlukan untuk mencapai coping yang efektif. Gross (1998) mendefinisikan regulasi emosi sebagai cara individu mempengaruhi emosi yang mereka miliki, kapan mereka merasakannya dan bagaimana mereka mengekspresikan emosi tersebut. Terdapat dua strategi dalam regulasi emosi yaitu pertama, cognitive reappraisal (penimbangan ulang kognitif) adalah suatu bentuk pemikiran ulang mengenai emosi yang dirasakan. Pada strategi cognitive reappraisal, individu akan berpikir kembali apakah akan mengeluarkan emosi yang dirasakan atau mengubah bentuk emosi tersebut di depan orang sekitarnya. Kedua, expressive suppression (penekanan secara sadar ekspresi emosi) adalah bentuk penekanan respon emosi yang dirasakan, individu akan menahan emosinya untuk tidak diekspresikan di depan orang 
sekitarnya (Gross, 1998). Regulasi emosi juga digunakan untuk menghadapi situasi yang menekan, sedangkan individu yang tidak dapat meregulasi emosi akan membuat kecenderungan berpikir negatif ketika menghadapi suatu peristiwa. Keberhasilan dalam meregulasi emosi akan memunculkan kesejahteraan subjektif, sedangkan kegagalan dalam meregulasi emosi akan berdampak pada kecemasan (Pratisti \& Prihartanti, 2012).

Berdasarkan penelitian Fransisca dan Lidiawati (2020), mahasiswa perantau beranggapan bahwa daerah perantauannya merupakan lingkungan yang tidak pasti, sehingga mereka bisa menggunakan dua strategi regulasi emosi tersebut saat beradaptasi di daerah rantau. Contohnya, expressive suppression dapat membantu individu mengalihkan emosi yang negatif, hal ini akan efektif ketika tidak ada orang lain yang memberikan dukungan. Melebihlebihkan emosi negatif ketika dihadapkan pada sebuah persoalan, bisa membantu individu lebih cepat dalam mencapai tujuan yang sifatnya jangka pendek, terlebih lagi jika individu mengabaikan efek jangka panjang dari emosi negatif tersebut (Szepsenwol \& Simpson, dalam Fransisca \& Lidiawati (2020).

$$
\text { Brener dan Salovey (dalam }
$$

Ratnasari \& Suleeman, 2017) mengungkapkan beberapa faktor yang dapat mempengaruhi regulasi emosi. Faktor pertama adalah usia, semakin bertambahnya usia individu maka relatif semakin baik regulasi emosinya (Fields, Stein \& Watson, 2004). Faktor kedua adalah keluarga, individu pada awalnya belajar dengan melihat orang tua dalam mengungkapkan emosinya. Peran orang tua dalam mengajarkan anak meregulasi emosi dapat menjadi faktor pendukung untuk anak belajar meregulasi emosinya. Pada penelitian Pratisti (2013) ditemukan bahwa peran orangtua dalam mengembangkan kemampuan regulasi emosi anak dapat dilakukan dalam tiga bentuk, yaitu sebagai model, pendidik dan pencipta iklim emosional dalam keluarga. Cara yang dapat dilakukan orangtua untuk mengembangkan regulasi emosi yang tepat bagi anak adalah memberikan teladan atau contoh pengelolaan emosi yang baik dan lebih terkontrol; memberikan pengarahan dan bimbingan pengelolaan emosi yang tepat; dan menciptakan iklim emosional yang baik, misalnya menciptakan keluarga yang penuh kasih sayang, lekat secara emosional, saling memberikan dukungan, dan memberikan kesempatan bagi anak-anaknya untuk menyuarakan apa yang dirasakan (Prasisti, 2013). Hal ini sejalan dengan hasil penelitian Rizkiana dan Indrawati (2019) bahwa terdapat hubungan positif antara dukungan sosial orang tua dengan regulasi emosi pada siswa. Faktor terakhir adalah lingkungan teman sepermainan. Teman sepermainan dapat menjadi sosok pengganti keluarga untuk berdiskusi dan bercerita. Teman sebaya dapat mendukung individu untuk belajar meregulasi emosi dalam lingkungan sepermainan. Hasil ini dipaparkan dalam penelitian Putri dan Coralia (2019) bahwa terdapat hubungan positif antara dukungan sosial dan regulasi emosi pada siswa korban bullying. Dukungan sosial yang paling berpengaruh dalam penelitian ini adalah belonging support, dimana individu merasa diterima dan menjadi bagian dari suatu kelompok serta adanya rasa kebersamaan.

Berdasarkan penelitian yang dipaparkan, terlihat bahwa dukungan dari lingkungan sekitar individu, baik orang tua maupun teman memiliki hubungan dengan regulasi emosi. Seperti hasil yang dipaparkan dalam penelitian Mahardika (2018) bahwa terdapat hubungan positif antara dukungan sosial dengan regulasi emosi atlet bulutangkis. Hal ini menunjukan bahwa dukungan sosial dan aspeknya memberikan pengaruh terhadap regulasi emosi. Sarafino dan Smith (2011) menjelaskan bahwa dukungan sosial merupakan bentuk penerimaan dari seseorang atau sekelompok orang terhadap individu yang menimbulkan persepsi dalam dirinya bahwa ia disayangi, diperhatikan, dihargai dan ditolong. 
Sarafino dan Smith (2011) membagi dukungan sosial dalam empat macam antara lain dukungan instrumental, informasional, emosional dan penghargaan. Dukungan instrumental merupakan bentuk dukungan berupa penyediaan materi seperti pinjaman uang, pemberian barang dan makanan. Dukungan informasional merupakan bentuk dukungan berupa pemberian informasi, saran, umpan balik mengenai situasi dan kondisi individu. Dukungan emosional adalah bentuk dukungan yang membuat individu merasa nyaman, diperdulikan dan dicintai sehingga individu dapat menghadapi masalah dengan lebih baik. Dukungan penghargaan adalah bentuk dukungan berupa penghargaan positif dan pemberian semangat terhadap individu (Dhamayantie, 2011).

Dukungan dari lingkungan sekitar diasumsikan akan membantu mahasiswa perantau dalam meregulasi emosinya, sehingga permasalahan yang dihadapi sebagai mahasiswa perantau dapat dicari jalan keluarnya dengan regulasi emosi. Kemampuan meregulasi emosi dapat membuat mahasiswa perantau memiliki keyakinan pada diri sendiri, atau memiliki kemampuan untuk bergantung pada diri sendiri dan menyadari kekuatan serta keterbatasan diri. Mahasiswa perantau merupakan mahasiswa yang tinggal jauh dari orang tua, sehingga orang terdekat yang dapat memberikan dukungan sosial selama di perantauan ialah teman sebaya. Sejalan dengan perkembangan usia remaja, yang juga merupakan usia mahasiswa perantau tahun pertama, teman sebaya memiliki peranan dalam kehidupan remaja, selain keluarga inti. Oleh karena itu perlu dilakukan penelitian mengenai dukungan sosial teman sebaya terhadap regulasi emosi mahasiswa perantau. Dukungan sosial merupakan salah satu faktor yang mempengaruhi regulasi emosi, namun penelitian mengenai peran dukungan sosial teman sebaya terhadap regulasi emosi mahasiswa perantau tahun pertama, belum banyak ditemukan.

\section{METODE PENELITIAN \\ Pendekatan}

Penelitian ini menggunakan pendekatan kuantitatif, dengan tipe pengujian asosiatif.

\section{Partisipan}

Penelitian ini melibatkan 120 partisipan yang berada dalam usia 17-21 tahun, mahasiswa tahun pertama dan merantau untuk berkuliah di Jakarta. Teknik pengambilan data dalam penelitian ini menggunakan accidental sampling.

\section{Instrumen}

Dalam penelitian ini, data mengenai dukungan sosial teman sebaya menggunakan instrumen yang dibuat oleh peneliti dengan teori dukungan sosial Sarafino \& Smith (2011). Berdasarkan data yang diperoleh, didapatkan hasil reliabilitas alat ukur Dukungan Sosial Teman Sebaya sebesar 0,972. Alat ukur regulasi emosi pada penelitian ini menggunakan Emotion regulation questionnaire (ERQ) yang dikembangkan oleh Gross \& John (2003). Berdasarkan data penelitian, maka koefisien reliabilitas yang diperoleh untuk dimensi cognitive reappraisal adalah 0,817 dan koefisien reliabilitas dimensi expressive suppression sebesar 0,610.

\section{Teknik Analisis Data}

Penelitian ini menggunakan metode analisa data dengan uji normalitas, uji linearitas dan uji regresi sederhana dengan SPSS 21.0 for Windows.

\section{ANALISIS DAN HASIL \\ Data Demografi}

Partisipan penelitian berjumlah 120 orang. Rentang usia partisipan adalah 17 sampai 21 tahun. Partisipan merupakan mahasiswa tahun pertama dan merantau untuk berkuliah di Jakarta. Berdasarkan hasil data demografi, terlihat bahwa mayoritas jenis kelamin partisipan adalah perempuan, sejumlah 82 orang, mayoritas beragama Islam dengan jumlah 105 orang. Suku Sunda merupakan mayoritas suku 
partisipan, yaitu sejumlah 35 orang. Daerah tempat dibesarkan partisipan mayoritas berasal dari Pulau Jawa dengan jumlah 78 orang. Mayoritas partisipan merantau selama 1-5 bulan dengan jumlah 73 orang. Berikut tabel persebaran data demografi partisipan:

Tabel 1

Persebaran Data Demografi

\begin{tabular}{|c|c|c|}
\hline Variabel & Jumlah & Presentase \\
\hline \multicolumn{3}{|l|}{ Jenis Kelamin } \\
\hline Laki-laki & 38 & $31,7 \%$ \\
\hline Perempuan & 82 & $68,3 \%$ \\
\hline \multicolumn{3}{|l|}{ Agama } \\
\hline Islam & 105 & $87,5 \%$ \\
\hline Kristen protestan & 9 & $7,5 \%$ \\
\hline Katolik & 2 & $1,6 \%$ \\
\hline Hindu & 1 & $0,8 \%$ \\
\hline Budha & 2 & $1,6 \%$ \\
\hline \multicolumn{3}{|l|}{ Suku/Etnis } \\
\hline Sunda & 35 & $29,2 \%$ \\
\hline Jawa & 30 & $25 \%$ \\
\hline Batak & 7 & $5,8 \%$ \\
\hline Lampung & 4 & $3,3 \%$ \\
\hline Betawi & 10 & $8,3 \%$ \\
\hline Aceh & 1 & $0,8 \%$ \\
\hline Minang & 8 & $6,6 \%$ \\
\hline Banjar & 2 & $1,6 \%$ \\
\hline Bugis & 2 & $1,6 \%$ \\
\hline Bali & 3 & $2,5 \%$ \\
\hline Tionghoa & 3 & $2,5 \%$ \\
\hline Minahasa & 2 & $1,6 \%$ \\
\hline Maluku Utara & 2 & $1,6 \%$ \\
\hline Melayu & 8 & $6,6 \%$ \\
\hline Kerinci & 1 & $0,8 \%$ \\
\hline Palembang & 1 & $0,8 \%$ \\
\hline Kupang & 1 & $0,8 \%$ \\
\hline \multicolumn{3}{|c|}{ Daerah tempat dibesarkan } \\
\hline Pulau Jawa & 78 & $65 \%$ \\
\hline Sumatera & 25 & $20,8 \%$ \\
\hline Kalimantan & 5 & $4,2 \%$ \\
\hline Sulawesi & 4 & $3,3 \%$ \\
\hline Papua & 2 & $1,6 \%$ \\
\hline Bali & 3 & $2,5 \%$ \\
\hline Maluku & 3 & $2,5 \%$ \\
\hline \multicolumn{3}{|l|}{ Lama merantau } \\
\hline $1-5$ bulan & 73 & $60,8 \%$ \\
\hline $6-12$ bulan & 29 & $24,2 \%$ \\
\hline$>12$ bulan & 18 & $15 \%$ \\
\hline
\end{tabular}


Pada penelitian ini dilakukan uji normalitas dengan kolmogorv smirnov dan ditemukan bahwa data pada penelitian ini berdistribusi normal, karena signifikansi $\mathrm{p}>0,05$ untuk cognitive reappraisal dan expressive suppression. Uji hipotesis yang dilakukan pada penelitian ini adalah uji regresi sederhana. Hasil uji regresi secara keseluruhan ditemukan bahwa terdapat peran dukungan sosial teman sebaya terhadap regulasi emosi mahasiswa perantau tahun pertama di Jakarta. Dukungan sosial teman sebaya memberikan peran terhadap cognitive reappraisal sebesar $7,2 \%$. Sementara itu peran dukungan sosial terhadap dimensi expressive suppression sebesar $2,1 \%$.
Berdasarkan hasil uji linearitas antara variabel dukungan sosial teman sebaya dengan strategi regulasi emosi cognitive reappraisal diperoleh nilai signifikansi (deviation from linearity) adalah 0,831. Maka dapat disimpulkan bahwa ada hubugan linear antara variabel dukungan sosial teman sebaya dengan strategi regulasi emosi cognitive reappraisal. Hasil uji linearitas antara variabel dukungan sosial teman sebaya dengan strategi regulasi emosi expressive suppression juga diperoleh nilai signifikansi 0,527. Oleh karena itu dapat disimpulkan bahwa terdapat hubungan yang linear antara variabel dukungan sosial teman sebaya dengan strategi regulasi emosi expressive suppression.

Tabel 2

Hasil Uji Regresi

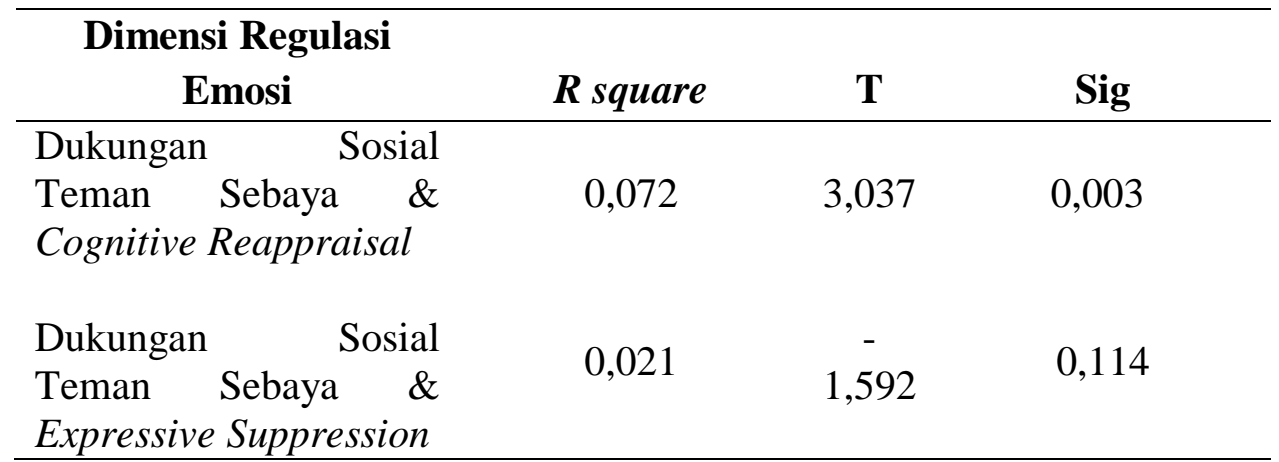

\section{DISKUSI}

Berdasarkan penelitian yang dilakukan, maka dapat disimpulkan bahwa dukungan sosial teman sebaya memiliki peran dalam jumlah kecil terhadap regulasi emosi mahasiswa perantau tahun pertama. Dukungan sosial teman sebaya berperan sebesar $7,2 \%$ terhadap strategi cognitive reappraisal dan $2,1 \%$ terhadap strategi expressive suppression.

Hasil penelitian menunjukkan bahwa terdapat peran dukungan sosial teman sebaya terhadap mahasiswa perantau tahun pertama di Jakarta. Dukungan sosial teman sebaya lebih berperan terhadap strategi cognitive reappraisal dibandingkan expressive suppression. Dukungan sosial teman sebaya berperan sebesar 7,2\% pada strategi cognitive reappraisal dan berperan sebesar $2,1 \%$ pada strategi expressive suppression. Hasil penelitian tersebut sesuai dengan hasil penelitian sebelumnya dimana beberapa penelitian menunjukkan bahwa cognitive reappraisal adalah salah satu strategi regulasi emosi yang paling efektif (Miles and Sheeran dalam Diponegoro, Ru'ya, \& Dewi, 2019). Cognitive reappraisal lebih efektif dalam mengubah pengalaman pengalaman emosional dibandingkan dengan cara lainnya karena cara ini relatif menghasilkan sedikit resiko 
baik secara fisiologi maupun kognitif (Gross \& Levenson, 1997).

Menurut Paramitha (2014), cognitive reappraisal dapat meningkatkan emosi positif dan mengurangi emosi negatif. Cognitive reappraisal muncul di awal pada saat emosi terjadi sehingga strategi dilakukan sebelum kecenderungan respon emosi benar-benar terjadi. Sedangkan expressive suppression kehadirannya lebih lambat pada proses regulasi emosi dan umumnya hanya memodifikasi tingkah laku dari kecenderungan respon emosi yang terjadi (Gross \& John, 2003). Individu yang terbiasa menggunakan cognitive reappraisal menunjukkan gejala depresi yang lebih rendah, lebih optimis, memiliki harga diri yang lebih tinggi, memiliki penguasaan lingkungan, penerimaan diri, keterampilan koping, serta hubungan interpersonal yang lebih baik (Cutuli, 2014). Expressive suppression dapat meningkatkan pengaruh negatif dan dapat membuat individu merasa buruk tentang dirinya dan bahkan menunjukkan gejala depresi (Gross \& John, 2004). Cutuli (2014) mengatakan bahwa individu yang melakukan expressive suppression merupakan individu yang kurang akan informasi yang dibutuhkan dalam merespon emosi.

Sanderson (2012) mengatakan bahwa mahasiswa membutuhkan dukungan emosional untuk mengatasi permasalahan dalam dunia kampus, contohnya putus hubungan dengan pasangan, hasil ujian yang jelek atau perceraian orang tua. Keinginan untuk diterima oleh kelompok teman sebaya sangatlah besar bagi remaja perantau, bagi mereka ancaman terbesar bukanlah keadaan tertekan berada diantara dua budaya tetapi tertekan bila tidak berada dalam kelompok manapun (Santrock, 2007). Hal tersebut menunjukkan bahwa mahasiswa perantau membutuhkan dukungan sosial dari teman sebaya.

Namun berdasarkan hasil penelitian, dukungan sosial teman sebaya hanya berperan sebesar $9,3 \%$ terhadap regulasi emosi mahasiswa perantau tahun pertama di Jakarta. Oleh karena itu, terdapat 90,7\% faktor lain yang dapat mempengaruhi regulasi emosi mahasiswa perantau tahun pertama di Jakarta. Pada penelitian Ratnasari dan Suleeman (2012), jenis kelamin menunjukkan perbedaan individu dalam melakukan regulasi emosi. Laki-laki cenderung melakukan strategi expressive suppression daripada perempuan. Secara umum di Indonesia, perempuan yang mengekspresikan emosinya lebih diterima dibandingkan laki-laki. Penelitian Diponegoro, Ru'ya dan Dewi (2019) menyebutkan agama memiliki efek secara tak langsung terhadap pengalaman emosional dengan membentuk proses regulasi emosi. Agama melakukan hal tersebut dengan memfasilitasi bentuk regulasi emosi baik yang ekstrinsik maupun intrinsik.

Penelitian Lu dan Wang (2012) mengenai eskpresivitas emosi, regulasi emosi, dan mood mahasiswa studi lintasethnik menyebutkan bahwa mahasiswa minoritas lebih banyak mengalami emosi negatif namun lebih sedikit mengadopsi strategi regulasi emosi. Penelitian Alfian (2014) juga diketahui bahwa mahasiswa dari suku Banjar mempunyai regulasi emosi positif yang lebih tinggi dari pada mahasiswa dari suku Jawa dan mahasiswa dari suku Bima. Nilai budaya mengenai hubungan interpersonal dan emosi membantu untuk menciptakan dan menegakkan norma-norma tentang regulasi emosi.

Keterbatasan dalam penelitian ini adalah jumlah responden yang dihasilkan belum mewakili berbagai etnis di Indonesia. Oleh karena itu untuk mendapatkan fenomena yang lebih beragam, penelitian selanjutnya sebaiknya memakai sampel yang lebih luas, mencakup seluruh mahasiswa perantau dari berbagai etnis yang ada di Jakarta maupun Jabodetabek. Keterbatasan lainnya adalah penggunaan alat ukur regulasi emosi yang dipakai dalam penelitian ini belum menghasilkan reliabilitas yang tinggi, karena peneliti berasumsi bahwa alat ukur merupakan hasil adaptasi dari luar negeri sehingga terdapat 
beberapa aitem yang memiliki arti ambigu atau sulit dimengerti. Peneliti juga tidak melakukan analisa tambahan pada data yang telah didapatkan dalam penelitian ini, oleh karena itu diharapkan dalam penelitian selanjutnya lebih menganalisis faktor lain yang dapat mempengaruhi regulasi emosi mahasiswa perantau tahun pertama.

\section{SIMPULAN}

Hasil penelitian menunjukkan bahwa terdapat peran dukungan sosial teman sebaya terhadap mahasiswa perantau tahun pertama di Jakarta. Dukungan sosial teman sebaya memiliki peran sebesar 7,2\% terhadap cognitive reappraisal. Sementara itu peran dukungan sosial teman sebaya terhadap strategi regulasi emosi expressive suppression sebesar 2,1\%. Hal ini menunjukkan bahwa dukungan sosial memiliki peran kecil dalam strategi regulasi emosi mahasiswa perantau. Dengan kata lain, mahasiswa perantau akan lebih mempertimbangkan secara kognitif emosi yang dirasakan untuk dikeluarkan daripada mengekspresikan emosi secara langsung kepada lingkungan sekitar. Oleh karena itu, bagi mahasiswa perantau tahun pertama dapat mencari dukungan sosial dari pihak lain untuk meningkatkan regulasi emosi yang dimiliki, karena pada awal tahun perkuliahan mahasiswa masih berada dalam tahap adaptasi dan proses pencarian teman sebaya.

\section{SARAN}

Berdasarkan hasil penelitian yang telah diperoleh, terdapat saran yang ditujukan untuk mahasiswa perantau dan bagi penelitian selanjutnya. Bagi mahasiswa perantau diharapkan dapat lebih bersosialisi dengan lingkungan sekitarnya agar dapat menemukan dukungan sosial dari pihak lain yang dapat meningkatkan regulasi emosi yang dimiliki. Bagi penelitian selanjutnya, apabila ingin meneliti tema yang sama diharapkan dapat menjangkau mahasiswa perantau tahun pertama yang tersebar di beberapa wilayah di Indonesia untuk mendapatkan fenomena yang lebih beragam. Peneliti pada penelitian selanjutnya diharapkan dapat melakukan modifikasi terhadap alat ukur regulasi emosi yang dikembangkan oleh Gross \& John (2003) dan menyesuaikan dengan budaya atau kebiasaan masyarakat Indonesia. Penelitian selanjutnya diharapkan dapat menggunakan variabel lain yang lebih berperan terhadap strategi regulasi emosi mahasiswa perantau tahun pertama di Jakarta.

\section{DAFTAR PUSTAKA}

Alfian, M. (2014). Regulasi emosi pada mahasiswa suku Jawa, suku Banjar, dan suku Bima. Jurnal Ilmiah Psikologi Terapan, 2(2), 263-275. https://doi.org/10.22219/jipt.v2i2.20 01 .

Behere, S. P., Yadav, R., \& Behere, P. B. (2011). A comparative study of stress among students of medicine, engineering and nursing. Indian Journal of Psychological Medicine, 33(2), 145-148. doi:10.4103/02537176.92064 .

Cosan, D. (2014). An evaluation of loneliness. The European

Proceedings of Social \& Behavioural Sciences, 103-110.

Cutuli, D. (2014). Cognitive reappraisal and expressive suppression strategies role in the emotion regulation: An overview on their modulatory effects and neural correlates. Frontiers in System Neuroscience, 8, 1-6. https://doi.org/10.3389/fnsys.2014.0 0175 .

Dhamayantie, E. (2011). Peranan dukungan sosial pada interaksi positif pekerjaan-keluarga dan kepuasan 
hidup. Jurnal Ekonomi dan Keuangan, 18(2), 181 - 193. doi: 10.24034/j25485024.y2014.v18.i2.1 42.

Diponegoro, A. M., Ru'ya, S., \& Dewi, L. (2019). Cognitive reappraisal muslim Indonesia di Belanda. Prosiding Seminar Nasional Magister Psikologi Universitas Ahmad Dahlan, 476-484.

Fields, F. B., Stein, R., \& Watson, T. L. (2004). Age differences in emotionregulation strategies in handling everyday problems. The Journals $O f$ Gerontology Series B Psychological Sciences And Social Sciences, 59(6), 261269. https://doi.org/10.1093/geronb/59.6. P261

Fransisca, T., \& Lidiawati, K.R. (2020). Pengaruh adult attachment terhadap strategi regulasi emosi pada mahasiswa perantau di universitas $X$. Jurnal Psikologi Talenta, 6(1), 89100.

https://doi.org/10.26858/talenta.v6i1 .13455 .

Gomanthi, K. G., Ahmed, S., \& Sreedharan, J. Jayadevan S. (2013). Causes of stress and coping strategies adopted by undergraduate health professions student in a university in the United Arab Emirates. SQU Medical Journal , 13(3), 437-441.

Gross, J. J. (1998). The emerging field of emotion regulation: an integrative review. Review of General Psychology, 2(3), 271-299. https://doi.org/10.1037/1089-

2680.2.3 .271.

Gross, J. J., \& John, O. P. (2003). Individual differences in two emotion regulation processes: Implications for affect, relationships, and wellbeing. Journal of Personality and Social Psychology, 85(2), 348-362. https://doi.org/10.1037/00223514.85.2.348.

Gross, J. J., \& Levenson, R. W. (1997). Hiding feelings: The acute effects of inhibiting negative and positive emotion. Journal of Abnormal Psychology, 106(1), 95-103. https://doi.org/10.1037/0021843X.106 .1.95.

Gunarsa, S. D., \& Gunarsa, Y. S. (2004). Psikologi praktis: Anak, remaja dan keluarga. BPK Gunung Mulia.

Halim, C. F. \& Dariyo, A. (2016). Hubungan psychological well-being dengan loneliness pada mahasiswa yang merantau. Jurnal Psikogenesis, 4(2), $170-181$ https://doi.org/10.24854/jps.v4i2.34 4.

Kemenristekdikti. (2018). Statistik pendidikan tinggi (Higher educational statistical year book). https://pddikti.kemdikbud.go.id/asse t/data/publikasi/Statistik\%20Pendidi kan\%20Tinggi\%20Indonesia\%2020 18.pdf. 
Lingga, R. W., \& Tuapattinaja, J. M. (2012). Gambaran virtue mahasiswa perantau. Predicara, 1(2), 60-68.

Lu, W., \& Wang, Z. (2012). Emotional expresivity, emotion regulation and mood in college students: a cross ethnic study. Social Behavior and Personality, 40(2), 319330.https://doi.org/10.2224/sbp. 2012.40.2.319

Mahardika, R. (2018). Dukungan sosial dan regulasi emosi atlet bulutangkis $P B$. PMS [Skripsi, Universitas Muhammadiyah Surakarta]. http://eprints.ums.ac.id/70031/1/NA SKAH\%20PUBLIKASI.pdf.

Nastalia, F. A. (2007). Ketabahan hati pada pekerja remaja perantau. Jurnal Psikologi, 1(1), 81-89.

Poegoeh, D. P., \& Hamidah. (2016). Peran dukungan sosial dan regulasi emosi terhadap resiliensi keluarga penderita skizofrenia. Insan, 1(1), 12

http://dx.doi.org/10.20473/jpkm.V1 I12016.12-21.

Paramitha, P. (2014). Hubungan antara selfmonitoring dengan strategi regulasi emosi pada pengurus organisasi kemahasiswaan [Skripsi, Universitas Indonesia]. http://lib.ui.ac.id/naskahringkas/201 6-06/S55150-

Pradina\%20Paramitha.

Pratisti, W.D., \& Prihartanti, N. (2012). Konsep mawas diri Suryomentaram dengan regulasi emosi. Jurnal
Penelitian Humaniora, 13(1), 16-29. https://doi.org/ 10.23917/humaniora.v13i1.911

Pratisti, W.D. (2013). Peran orangtua dalam perkembangan kemampuan regulasi emosi anak: Model teoritis. Prosiding Seminar Nasional Parenting, 322-333.

Putri, S. D., \& Coralia, F. (2019). Hubungan dukungan sosial dengan regulasi emosi pada siswa korban bullying di SMPN "X" Kota Bandung. Prosiding Psikologi, 134-140.

Ratnasari, S., \& Suleeman, J. (2017). Perbedaan regulasi emosi perempuan dan laki - laki di perguruan tinggi. Jurnal Psikologi Sosial, 15(1), 35-46. https://doi.org/ 10.7454/jps.2017.4.

Rizkiana, L., \& Indrawati, E. S. (2019). Hubungan antara dukungan sosial orang tua dengan regulasi emosi pada siswa kelas VIII MTSN Bawu Jepara. Jurnal Empati, 8(1), 76-81.

Sanderson, A. C. (2012). Health psychology $\left(2^{\text {nd }}\right.$ ed.).Wiley.

Saniskoro, B. S., \& Akmal, S. Z. (2017). Peranan penyesuaian diri di perguruan tinggi terhadap stres akademik pada mahasiswa rantau di Jakarta. Jurnal Psikologi Ulayat, 4(1), $\quad 95 \quad$ - $\quad 106$. https://doi.org/10.24854/jpu1201782.

Santrock, J.W. (2007). Adolescence ( $7^{\text {th }}$ ed.). Erlangga. 
American College Health, 60(5),

Sarafino, E. P., \& Smith, T. W. (2011). Health psychology (7th ed.). Wiley.
415-419.

doi:

Thurber, C.A., \& Walton,E.A. (2012).

Homesickness and adjustment in

university students. Journal of 